\title{
Future Services for District Heating Solutions in Residential Districts
}

\author{
Hannele Ahvenniemi*, Krzysztof Klobut \\ VTT Technical Research Centre of Finland, Espoo, Finland \\ e-mail: hannele.ahvenniemi@vtt.fi
}

\begin{abstract}
Cite as: Ahvenniemi, H., Klobut, K., Future Services for District Heating Solutions in Residential Districts, J. sustain
\end{abstract} dev. energy water environ. syst., 2(2), pp 127-138, 2014, DOI: http://dx.doi.org/10.13044/j.sdewes.2014.02.0012

\begin{abstract}
The underlying assumption of this study is that in order to retain the competitiveness while reaching for the EU targets regarding low-energy construction, district heating companies need to develop new business and service models. How district heating companies could broaden their perspective and switch to a more service-oriented way of thinking is a key interest of our research. The used methods in our study are house builder interviews and a questionnaire. With the help of these methods we discussed the potential interest in heating related services acquiring a comprehensive understanding of the customer needs. The results indicate the importance of certain criteria when choosing the heating system in households: easiness, comfort and affordability seem to dominate the house builders' preferences. Also environmental awareness seems to be for many an important factor when making a decision about the heating of the house. Altogether, based on the results of this study, we suggest that the prospects of district heating could benefit from highlighting certain aspects and strengths in the future. District heating companies need to increase flexibility, readiness to adopt new services, to invest in new marketing strategies and improving the communication skills.
\end{abstract}

\section{KEYWORDS}

District heating, Heating related services, Customer preferences, Heating system, Ecological values

\section{INTRODUCTION}

Traditionally district heating has had a strong position in the Finnish heating market with almost half of the buildings using district heating as the primary heating method [1]. However, the tightening energy-efficiency requirements as well as increasing competition are posing new challenges for district heating companies. A number of studies have suggested that in order to retain its competitiveness district heating companies need to broaden their business perspective, provide new business models and switch to a more service-oriented way of thinking [2,3]. Even if district heating is widely used in Finland, only $6.5 \%$ of single family houses use district heating as their primary heating method [4] hence providing a new market segment for district heating companies.

Finland is committed to the EU 2030 goals of reducing greenhouse gas emissions by $40 \%$ below the 1990 level, increasing use of renewable energy and improving energy efficiency [5]. As heating of buildings account for about $25 \%$ of the total energy consumption in Finland [6] energy efficiency of buildings and heating methods have a key role in fighting against climate change. A few measures have been developed in Finland to support district heating which is seen as a promising heating method regarding

\footnotetext{
* Corresponding author
} 
the objective of reducing $\mathrm{CO}_{2}$ emissions [7, 8]. Finnish households' decisions to convert their electrical or oil heating to district heating is supported by an energy subsidy (up to $40 \%$ of the connection fee) provided by The Housing Finance and Development Centre of Finland (ARA) [9]. The land use plan can also oblige buildings to join the district heating network [11] although this possibility has been little used in Finland. In a Swedish study [10] subsidies were identified as a functioning means in encouraging household to convert to district heating which gives motivation to continue with energy subsidies in Finland as well.

\section{Background}

To be able to understand the future development needs of district heating companies and present suggestions for future actions it is necessary to understand the needs of customers. Only limited amount of studies about Finnish householders' attitudes regarding heating systems has been carried out and therefore literature from Sweden has also been addressed in our background study. According to a study by Syvänen and Mikkonen [12] operation reliability and safety are the most important factors when Finnish households select the heating system. After this come savings in energy costs, low procurement cost and easiness of installation. Environmental aspects are at the bottom of the list. The same study also presents that ignorance and availability of only complicated technical information might bring difficulty to decision making. Also Mäkelä et al. [3] point out that if the differences in costs between different heating systems are low decisions are made based on easiness, operation reliability and comfort. These findings are in line also with a study about Swedish homeowners' perceptions of innovative heating systems [13] according to which economic factors, functional reliability and indoor air quality are considered as much more important than environmental factors. Sernhed and Pyrko [2] present that the decision is usually not a rational choice as it is affected by factors such as comfort of temperature, aesthetics and usability.

Different future scenarios have been presented in a few studies. According to Pesola et al. [14] new smart and flexible solutions, for example decentralised production, heat storing systems, real-time monitoring, optimisation, consumption consulting and new pricing schemes are needed in the future. New business models will be needed as hybrid heating systems will become more common. A Swedish study by Larsson and Persson [15] also predicts that those district heating companies which cannot offer low-carbon services will not succeed in the future competition. Aggregate service packages will be needed in the future and these services need to be developed from the customer's point of view [3]. For example the "keys in the hand"- service is already preferred by customers who find it difficult to make a decision about something beyond their comprehension [12].

Some studies have presented that in order to attract new customers district heating companies need to improve their marketing and communication skills $[15,16]$ and new services related to information sharing should be developed. According to the study by Syvänen and Mikkonen [12] customers would be highly interested in an internet service which would allow comparing different energy solutions. Simultaneously the site could function as a forum for customers to exchange experiences and knowledge. It has also been presented that as district heating business will need to evolve towards service business, the customers need to be provided with more guidance and consulting services in the future [17]. District heating has been criticised for not taking sufficiently into account preferences and needs of different customers. Usually district heating companies have only information about buildings, and not about any social factors which also have a 
large impact on the decision making [16]. According to Isaksson [18] several factors affect the decision making of Swedish house owners and customers also differ from each other to a large extent, depending on the life cycle of the building. Earlier experiences and beliefs regarding the heating systems as well as friends' opinions might affect the decision greatly. The importance of interpersonal communication has also been highlighted by Mahapatra et al. [13].

\section{Research Questions}

The aim of our study was to provide a profound understanding of Finnish households' attitudes, perceptions and values regarding different heating systems and heating related services. To reliably foresee the future of district heating it is necessary to understand the customer needs, preferences and new trends driving the development of heating systems. The main research questions aimed to be answered by this study are listed as follows:

- What are the house builders' preferences, expectations, assumptions and prejudices regarding district heating and other heating methods?

- Which are the heating related services that customers want and what kind of service models are needed to fulfil the customer needs?

- What is the role of environmental concern regarding households' preferences?

- How should district heating companies evolve to promote district heating for single-family houses, row houses and semi-detached houses?

\section{Methods}

The research was carried out in two stages and the research methods were interviews and a survey. The first target was to identify customer needs and during spring 2013 ten in-depth, semi-structured interviews with single-family house builders were carried out. The questions considered reasons for choosing a certain type of heating system, interest for renewable energy, encountered problems, criteria for decision-making and finally, interest for certain heating related services. These interviews were beneficial also for developing the survey which was used in the second stage.

The survey, targeted for a wide group of potential house builders and house owners, was used for acquiring a comprehensive understanding about customer perceptions regarding heating systems and the need for new services. The survey was distributed and responses were collected at the annual Finnish Housing Fair organised in Hyvinkää, Southern Finland, in the summer 2013 and by email to housing associations (of single family houses, row houses and semi-detached houses) around Finland. The target group of the survey consisted of residents of detached houses, row houses and semi-detached houses who would be potential for either build a new house or change the heating system.

The questionnaire started by basic questions regarding the respondents such as age, place of domicile, type of current housing and number of family members. Next it was inquired whether the respondent was planning to build a new house in the future and how this would be done. The current heating system and the satisfaction level regarding it was queried next after which a series of questions about households' attitudes regarding different heating systems, criteria for decision-making and interest for heating related services. In the last part the respondent was asked to indicate how much extra he/she would be willing to pay for eco-friendly heating. 


\section{RESULTS}

\section{Interviews}

The ten interviewed house builders were currently building their own houses in one of the two new residential areas in Hyvinkää town in southern Finland. One of the areas had been chosen for the annual Finnish Housing Fair and therefore the house owners' preferences might differ from a typical Finnish house builder's preferences to some extent. However, some conclusions about house builder needs could be identified. One third of the interviewees had chosen district heating as the main heating method. These choices were made based on trust in operation reliability and safety of the system. Also the costs were mentioned as a reason for the choice and the importance of the operational costs over the life-cycle were highlighted more than the initial investment costs.

The house builders residing in the Housing Fair area were exceptionally eager to choose new types of heating systems with rather high initial costs but with prospective low heating costs. Also ecological values seemed to be rather important for these interviewees, which indicate that eco-friendliness might be becoming an increasingly significant criteria for some house builders. However, as the Finnish Housing Fair areas normally serve as forerunners and trend-setters [19] it can be assumed that the builders in this area might not represent a typical Finnish house builder but instead they are important as early adopters of innovative technologies and for diffusion of innovations [20].

\section{Questionnaire for potential house builders and district heating customers}

Altogether 320 (accepted) responds were received. It is impossible to estimate the response rate because of the lack of information of the number of people who received the request to fill in the questionnaire but it is assumed to be low. If the respondent did not respond to more than half of the questions in the survey, the answers were not considered at all.

A large majority of the respondents $(82 \%)$ resided in single-family houses and the rest lived in row houses $(6 \%)$ or semi-detached houses $(11 \%)$. The average household size of was 2.6 people. Two thirds of the respondents were men and the average age was 55.5 years. The respondents were geographically distributed around the whole country but most resided in southern Finland.

Plans to build a house. The respondents were asked whether they were planning to build a single-family house in the coming years. Most of the respondents (73\%) did not have any plans to build a house in the future. Only five out of the 320 respondents were currently building and six were currently planning to build. The rest were either planning to build during the next five years $(3 \%)$ or possibly during the next ten years $(14 \%)$.

Next the respondents were asked how they would prefer to plan and build their house. Nearly two-thirds of the respondents chose the option of a prefabricated house whereas the rest preferred an individually planned house. Choosing an all-inclusive so called "keys-in-the-hand"- package house (45\%) and using contractors when building the house $(42 \%)$ were almost as popular options. The rest chose the option of building the house by themselves. Regarding energy-efficiency, class B was the most popular option, chosen by $46 \%$ of the respondents. The rest were favouring A-class buildings (29\%) and C-class buildings $(25 \%)$. (In the current Finnish Building Code C-class is the lowest energy efficiency requirement for new residential buildings [21]). The responses are summarised in Table 1. Only small differences were identified between those respondents who were currently building/planning or possibly planning within five years and the other 
respondents. Those who were planning to build currently or in near future were slightly more in favour of using contractors (53\%) instead of choosing a keys-in-the hand service (32\%) and building the house individually (42\%) instead of using a prefabricated solution $(58 \%)$ compared to other respondents.

Table 1. Respondents' thoughts on how to plan and construct a new house (amount of responses)

If you would construct a house, how would you

a) Plan the house? I would choose... an individually planned house a prefabricated house

87 153

b) Build the house? I would...

\begin{tabular}{lcc}
$\begin{array}{c}\text { choose a "keys-in-the-hand" } \\
\text { delivery }\end{array}$ & $\begin{array}{c}\text { subcontract parts of the } \\
\text { construction } \\
107\end{array}$ & $\begin{array}{c}\text { mainly build it myself } \\
101\end{array}$ \\
performance class would you choose? & & 31 \\
\hline Class A & Class B & Class C \\
74 & 121 & 66 \\
\hline
\end{tabular}

The current heating system and the satisfaction level regarding it. More than half of the houses where the respondents were residing were heated by electricity $(57 \%)$. The next common heating systems were oil heating (18\%), ground-source heat pumps $(14 \%)$ and district heating (9\%). Wood-fired heating was a rarely used primary heating method (3\%) but a very common secondary heating source used by almost two thirds of the respondent. Also heat pumps were rather common secondary heating sources, used by more than one third of the respondents. Only few respondents used solar heat collectors. District heating was much more common heating method in row houses and semi-detached houses $(22 \%)$ than single-family houses (5\%). Ground-source heat pumps were not as common in row houses and semi-detached houses (3\%) as in single-family houses $(17 \%)$.

Satisfaction with the current heating system was quite high as $35 \%$ of the respondents were very satisfied, $53 \%$ were quite satisfied and only $8 \%$ were quite unsatisfied and $1 \%$ very unsatisfied with it. More than half (59\%) of the households also did not have any plans to change their heating system in the future. However, $13 \%$ responded that they might change the heating system within the coming five years and $6 \%$ was currently planning the change. The rest were planning to possibly change the heating system later in the future $(15 \%)$ or they did not know $(7 \%)$.

Ground-source heat pump users were the most satisfied with their heating system as $78 \%$ of these households responded that they are very satisfied and $17 \%$ were quite satisfied. Also households using district heating were contented as $65 \%$ were very satisfied and $31 \%$ quite satisfied with their heating system (see Table 2). Households with electrical heating and oil heating were far less satisfied. None of the households with ground-source heat pumps and only one household with district heating was planning to change the heating system. Those households who responded that they are planning to change the heating system currently or in the near future were using oil heating (eight households) or electrical heating (11 households). The respondents had an opportunity to indicate the reasons for changing the heating system and almost all responds were related to either economic reasons (life cycle costs or stability of the expenses) or ageing of the equipment. Also, a few respondents referred to environmental reasons and preference of local energy production. These results are highly similar to the results in the study by 
Mahapatra et al. [13] according to which approx. $92 \%$ of the heat pump users and $84 \%$ of district heat users were highly satisfied with their heating system whereas households with oil boilers and resistance heaters were much less satisfied, about $30 \%$ of them planning to install a new heating system. However, in our study the numbers of respondents with different types of heating systems were not equal and therefore the result should only be regarded as indicative.

Table 2. Satisfaction level of the current heating method by households using different heating systems

\begin{tabular}{lcccccc}
\hline & $\mathrm{N}$ & $\begin{array}{c}\text { Very } \\
\text { satisfied }\end{array}$ & $\begin{array}{c}\text { Quite } \\
\text { satisfied }\end{array}$ & $\begin{array}{c}\text { I do not } \\
\text { know }\end{array}$ & $\begin{array}{c}\text { Quite } \\
\text { unsatisfied }\end{array}$ & $\begin{array}{c}\text { Very } \\
\text { unsatisfied }\end{array}$ \\
\hline $\begin{array}{l}\text { Households with } \\
\text { electrical heating }\end{array}$ & 173 & $22 \%$ & $61 \%$ & $3 \%$ & $12 \%$ & $2 \%$ \\
$\begin{array}{l}\text { Households with } \\
\text { ground-source heat } \\
\text { pump }\end{array}$ & 41 & $78 \%$ & $17 \%$ & $5 \%$ & $0 \%$ & $0 \%$ \\
$\begin{array}{l}\text { Households with } \\
\text { district heating }\end{array}$ & 26 & $17 \%$ & $8 \%$ & $0 \%$ & $1 \%$ & $0 \%$ \\
$\begin{array}{l}\text { Households with oil } \\
\text { heating }\end{array}$ & 75 & $28 \%$ & $64 \%$ & $3 \%$ & $5 \%$ & $0 \%$ \\
\hline
\end{tabular}

Popularity of and criteria for choosing different heating systems. The respondents were also requested to rate different heating methods according to the probability that they would choose such system, on the scale from 1 to 5 (1=not likely at all, 5=very likely). Among all respondents ground-source heat pumps (scoring 4.2), other types of heat pumps (3.7), solar heat collectors (3.5) and wood-fired heating (3.1) were the most popular heating methods whereas electric heating (2.3), fuel oil (1.4) and gas heating (1.3) were less likely to be chosen (see Figure 1). Differences between single-family house residents and row house/semi-detached building residents were not significant except for district heating which was much more popular in row houses/semi-detached houses (scoring 3.3) than in single-family houses (2.4).

\section{If you would change the heating system of your home, how likely would you be to choose the following ones? (1=not likely at all, $5=$ =very likely) $(\mathrm{N}=\mathbf{2 0 8})$}

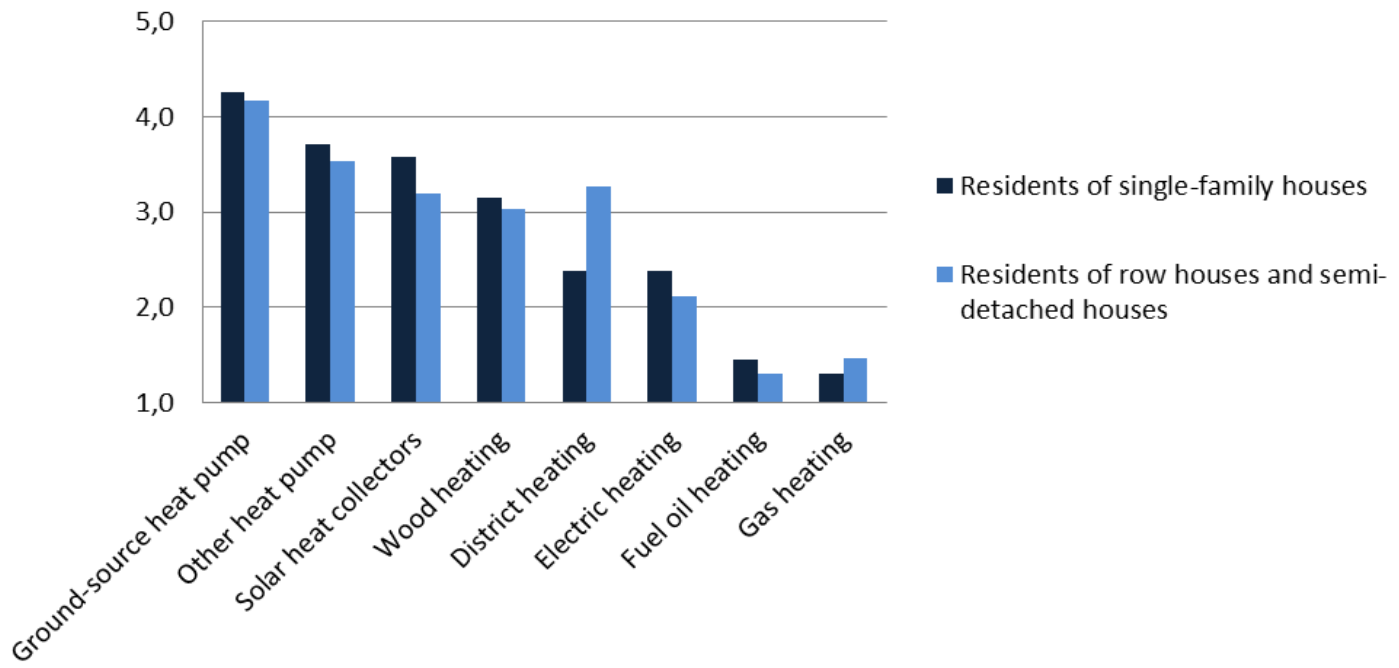

Figure 1. Popularity of different types of heating systems 
Respondents were asked to rank different criteria when choosing the heating system, on the scale from 1 to 5 (1=not important at all, $5=$ very important). Operation reliability (scoring 4.9), good quality (4.7) and affordable operation costs (4.7) were highly important factors for households. Next important criteria were easy installation and maintenance (4.4), eco-friendliness (4.0) and affordable procurement costs (3.7). Much less importance was given to pleasant exterior, locality of the product, popularity of the brand and recommendation by sales personnel. Also, very little weight was put on recommendation of friends. This was surprising considering the study by Mahapatra et al. [13], which emphasises interpersonal communication as an important source of information regarding heating systems. No remarkable differences between single family house and row house/semi-detached dwelling owners could be identified (see Figure 2).

\section{Importance of certain criteria when choosing the heating system for your home (1=not important at all, 5=very important) ( $N=271)$}

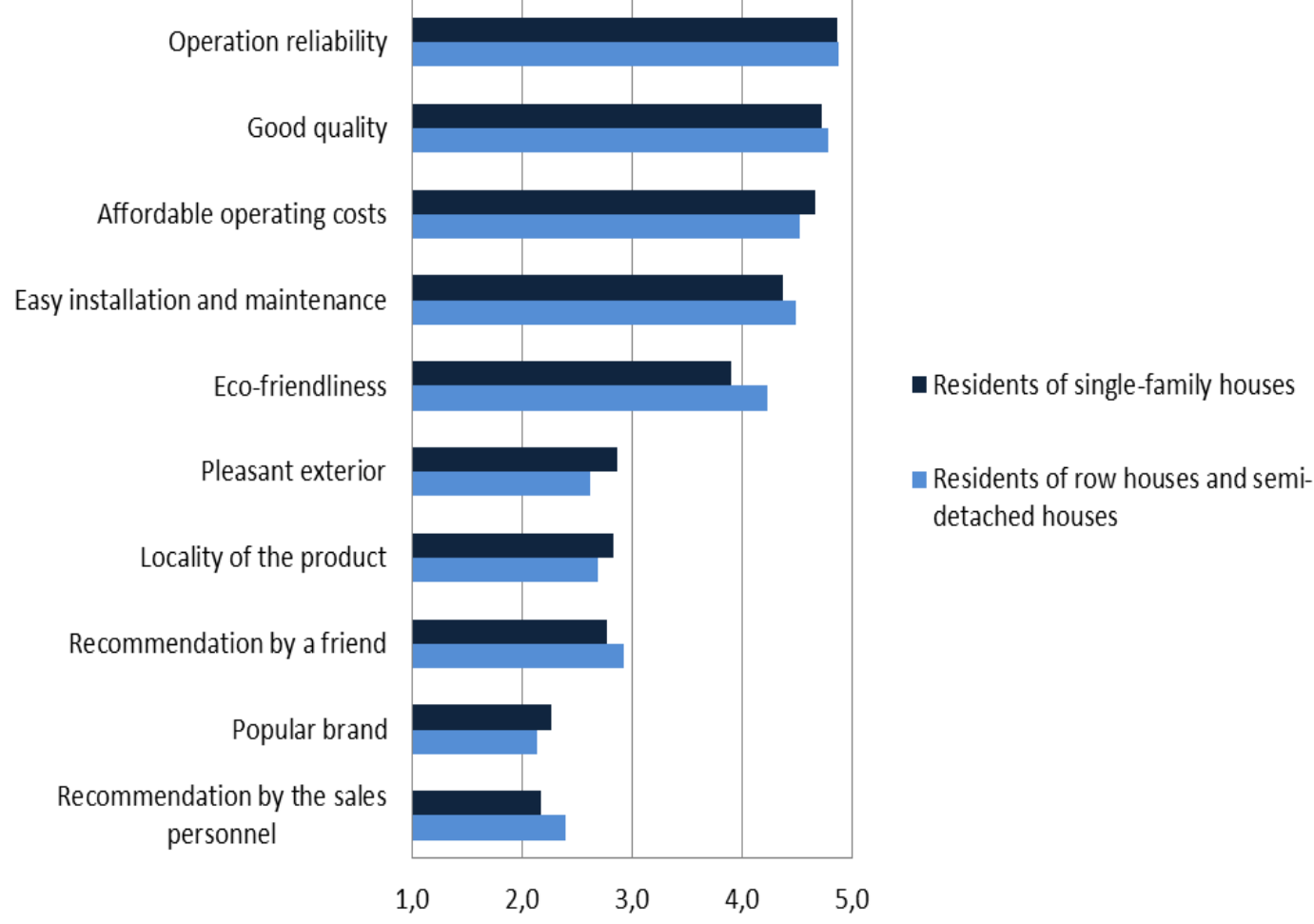

Figure 2. Importance of different criteria when choosing the heating system

When the respondents were asked to indicate their worries related to choosing a heating system, on the scale from 1 to 5 , (1=not worrying at all, 5=very worrying), unpredictability of the heating expenses and energy consumption were by far the most worrying aspects, both scoring 3.7 (see Figure 3). Also the other presented aspects (lack of trust for the vender, difficult and/or technical language and lack of time) were considered as quite worrying. 


\section{How much are you worried about the following aspects when choosing a heating system? (1=not worried at all, $5=$ very worried)}

$(\mathrm{N}=\mathbf{2 9 3})$

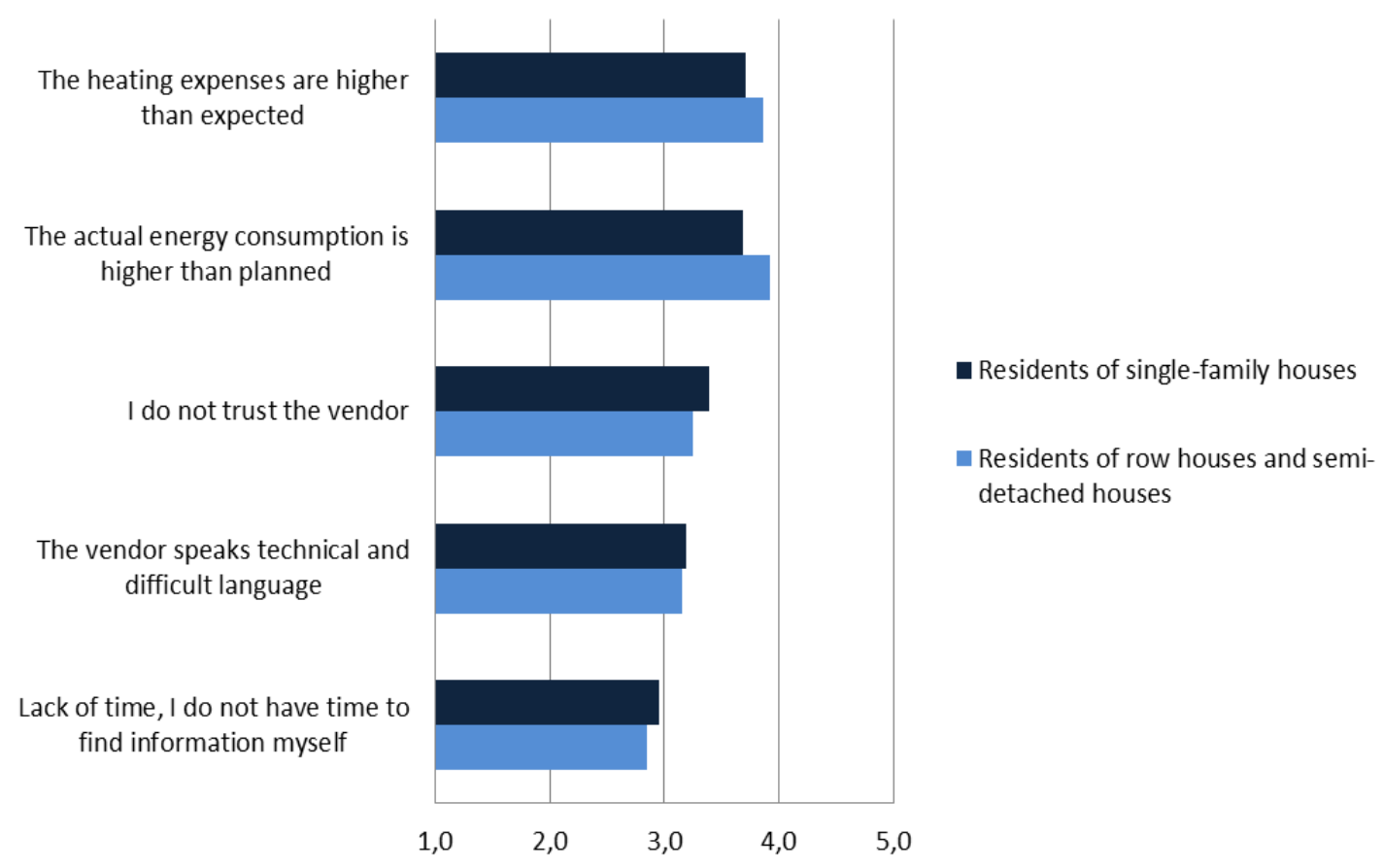

Figure 3. Worrying aspects related to choosing the heating system

Heating related services. Interest in different heating related services was enquired by presenting different services and asking the respondents to rate them on the scale from 1 to 3 (1=not much interested, $3=$ very interested). Highest interest was expressed for solar heating connected to the main heating system (scoring 2.4) but several other services also scored very high (energy consumption monitoring service, heating system as a "keys-in-the-hand service" and an internet service enabling comparison of different heating methods scored 2.3). Slightly less interest was expressed for prolonged payback time for procurement and 24/7 maintenance service (see Figure 4).

Readiness to pay more for eco-friendliness or better services. Finally, the respondents were asked to indicate how much more they would be willing to pay for eco-friendly heating. More than one third of the respondents $(36 \%)$ were willing to pay "nothing" and another third (31\%) chose 1-3\% more. The rest were willing to pay $3-5 \%$ extra (18\% of the respondents), $5-10 \%$ extra (9\% of the respondents) and a few respondents even 10-15\% and more than $15 \%$ extra (see Figure 5). These results imply that paying for eco-friendliness has not yet reached popularity among a large group of people. However, a small minority seems to have adopted ecological values to a high level and are willing to also pay for these values.

The respondents also had a possibility to mention other reasons why they could be willing to pay more for the heating. Most of these responses were related to good functionality and usability of the heating system. Other rather often mentioned reasons were cost savings during the whole life cycle of the building, stability and predictability of the energy costs and local energy production. 


\section{How intertested would you be in the following heating related services? (1=not much interested , 3=very interested) \\ $(\mathrm{N}=\mathbf{2 8 6})$}

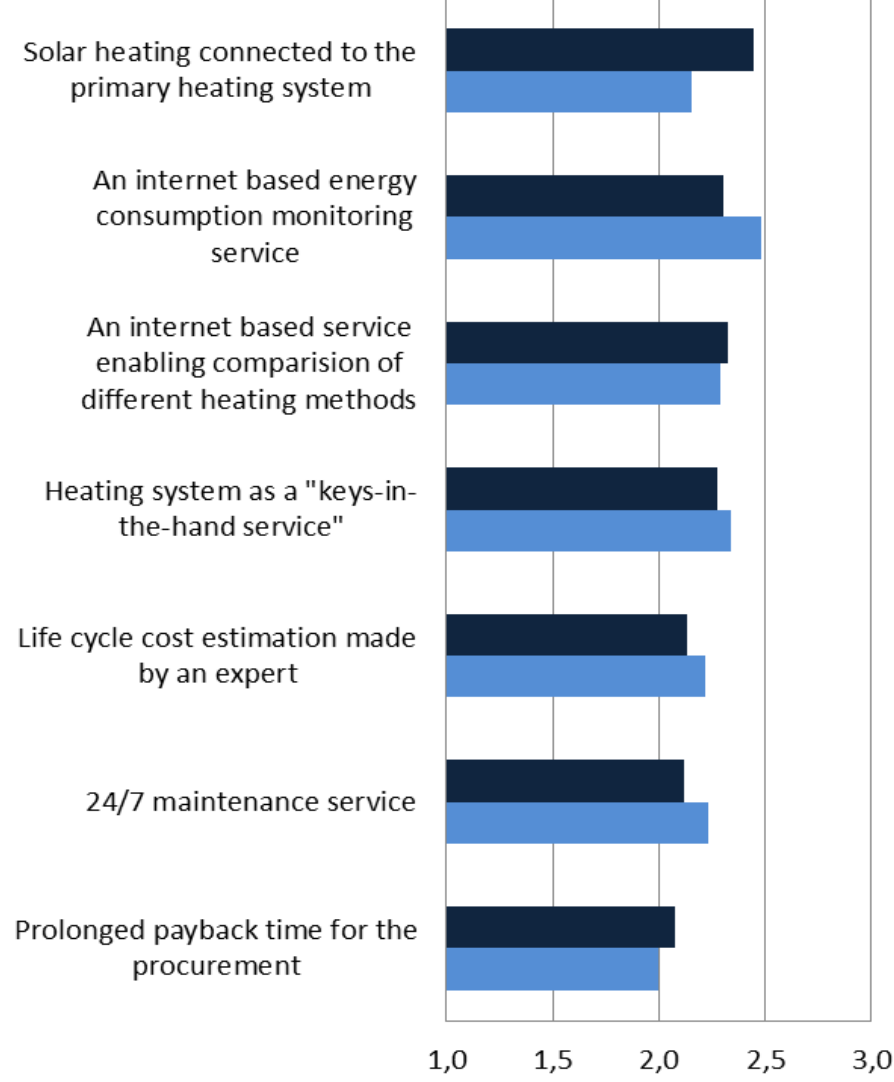

- Residents of single-family houses

nesidents of row houses and semi-detached houses

Figure 4. Interest in heating related services

\section{How much extra would you be willing to pay for eco-friendly heating? $(\mathrm{N}=315)$}

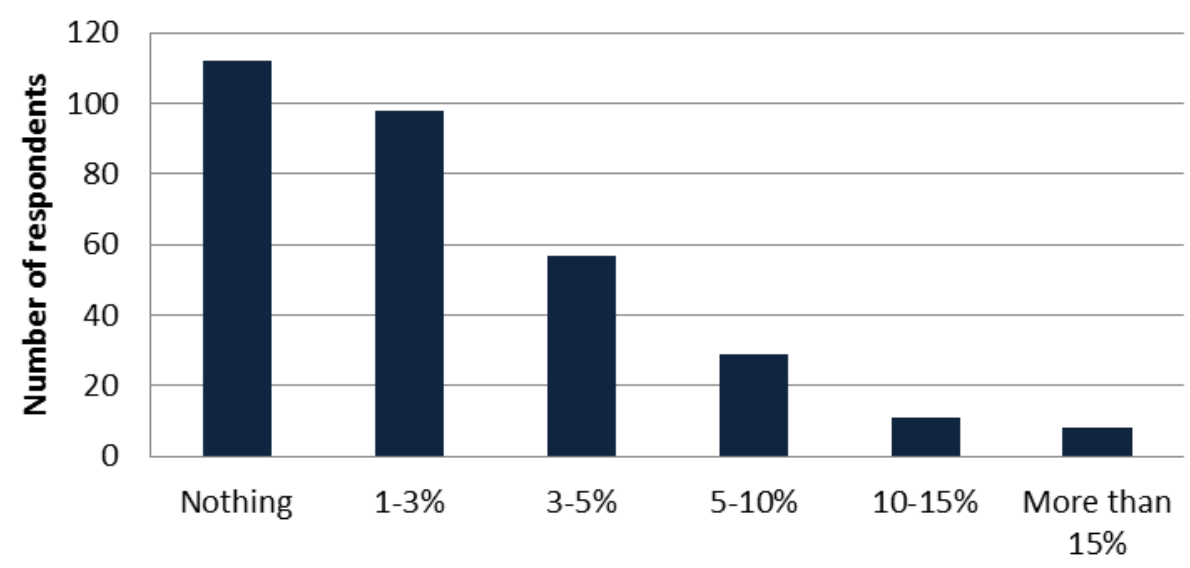

Figure 5. Willingness to pay extra for eco-friendly heating 


\section{DISCUSSION AND CONCLUSIONS}

The results indicate the importance of certain criteria when choosing the heating system in households: easiness, comfort and affordability seem to dominate the house builders' preferences which is in line with results from earlier studies $[3,12,13]$. Low life-cycle costs are naturally highly important for house owners whereas the initial investment costs seem to be somewhat less significant. Also environmental aspects were highlighted in the questionnaire by relatively many respondents and interest in renewable energy such as solar heating was quite high. However, it remains unclear whether these respondents would be willing to pay for eco-friendliness after all. As several earlier studies have pointed out it seems that even if the environmental awareness is increasing it still does not play a remarkable role in households' decision making $[12,13]$.

Based on the results of our study we recommend the following things for district heating companies to keep up with the tightening competition of the heating market. First, traditional strengths of district heating such as easiness, comfort, good operation reliability and stability of costs should be highlighted when marketing district heating to potential customers. Second, there seems to exist an interest in certain services such as energy consumption monitoring, keys-in-the-hand delivery of the heating system and possibility to compare different heating systems. As can be seen in the increasing interest for prefabricated houses and keys-in the-house solutions in house construction [22], the same interest for easiness and ready-made solutions seem to exist also when it comes to heating systems. Third, it might be beneficial for district heating companies to develop their services embracing ecological values. Providing customers with low carbon energy, for example by using centralised solar thermal, would ensure meeting the customer needs in the future. And fourth, as has been pointed out by earlier studies [15, 16], district heating companies need to invest in marketing and communication skills. As was pointed out in the study by Mahapatra and Gustavsson [10] marketing campaign can be successful in motivating people to convert their heating system to district heating. Also, our study reveals the limited trust that the customers hold towards salespersons of the heating companies.

Even if this study sheds a light on the importance of ecological values for households we however suggest that further research about impacts of these values on real decisions should be carried out. Renewable energy does undoubtedly sound attractive to a large majority of people but whether people have willingness to implement these kinds of solutions in real life still remains unclear and should be a matter of future studies. Also, criteria for choosing the heating system for a new building and converting the existing heating system to a new one might be rather different, but this aspect was not sufficiently studied in this research due to the small number of current house builders responding to the questionnaire.

\section{ACKNOWLEDGEMENT}

Acknowledgements: This research was carried out as part of the TUKALEN - Future district heating solutions for residential districts - project supported by Tekes - the Finnish Funding Agency for Technology and Innovation, and a group of Finnish district heating companies.

\section{REFERENCES}

1. Finnish Energy Industries, Energy year 2012, District Heating, 2013. (in Finnish) 
2. Sernhed, K. and Pyrko, J., Make the heat hotter! Marketing district heating to households in in detached houses, Lund University, Sweden, The $11^{\text {th }}$ International Symposium on District Heating and Cooling, Reykjavik, 2008.

3. Mäkelä, V. M., Nousiainen, H., Tuunanen J., Solutions used for moving the customer interface, RajaLämpö project, Mikkeli University of Applied Science, Mikkeli, 2005. (in Finnish)

4. Statistics Finland, Residential energy consumption, 2012, http://www.stat.fi/til/asen/2012/asen_2012_2013-11-13_tau_002_fi.html, [Accessed 01-March-2014] (in Finnish)

5. Europa.eu, 2030 climate and energy goals for a competitive, secure and low-carbon EU economy, http://europa.eu/rapid/press-release_IP-14-54_en.htm, [Accessed 05-March-2014]

6. Statistics Finland, Energy procurement and consumption, the $4^{\text {th }}$ quarter, http://www.stat.fi/til/ehk/2012/04/ehk_2012_04_2013-03-22_tie_001_fi.html, [Accessed 05-March-2014] (in Finnish)

7. Climate guide, Climat impacts of heating of buildings, http://ilmasto-opas.fi/fi/ilmastonmuutos/hillinta/-/artikkeli/73fa2827-42d1-4fd7-a75 7-175aca58b441, [Accessed 03-March-2014] (in Finnish)

8. Connolly, D., Lund, H., Mathiesen, B.V., Werner, S., Möller, B., Persson, U., Boermans, T., Trier, D., Østergaard, P.A., Nielsen, S., Heat Roadmap Europe: Combining district heating with heat savings to decarbonise the EU energy system, Energy Policy, 65, pp. 475-489, http://dx.doi.org/10.1016/j.enpol.2013.10.035

9. The Housing Finance and Development Centre of Finland (ARA), Guide for refurbishment and energy grants 2014, ARA, 2014. (in Finnish)

10. Mahapatra, K. and Gustavsson, L., Influencing Swedish homeowners to adopt district heating systems, Applied Energy, 86, pp. 144-154, 2009, http://dx.doi.org/10.1016/j.apenergy.2008.03.011

11. Finlex, Maankäyttö- ja rakennuslaki, http://www.finlex.fi/fi/laki/ajantasa/1999/19990132 , [Accessed 04-March-2014].

12. Syvänen, T. and Mikkonen, K., Local energy services, anyone? Survey: Homeowners' housing companies' and leisure residents' opinions on various energy solutions and on new local energy services, Taloustutkimus Oy, Sitra report 60, Helsinki, 2011. (in Finnish)

13. Mahapatra, K., Gustavsson, L. and Nair, G., Swedish homeowners' perceptions of innovative heating systems - results of three surveys, ECEEE Summer study, La Colle Sur Loupe, Côte d'Azur, France, June 1-6, 2009.

14. Pesola, A., Bröckl, M., Vanhanen, J., Smart district heating system and its potential, Gaia Consulting Oy, 2011. (in Finnish)

15. Larsson, O. and Persson, A., How to make district heating greener? Customer driven development, Report 2012:7. Svensk Fjärrvärme AB, 2012. (in Swedish)

16. Persson, T. and Sernhed, K., Swedish district heating companies' sales strategies for residential districts, Värmegles 2004:13, Svensk Fjärrvärme AB, 2004. (in Swedish)

17. Heikkilä, T., Pricing and tariff structures of Finnish district heating, Master thesis, Metropolia University of Applied Science, 2011. (in Finnish)

18. Isaksson, C., Decent warm and pleasant, A survey of households' relation to energy with focus on households' choices and use of heating systems in small houses, Linköping University, 2005. (in Swedish) 
19. The Finnish Housing Fair, http://www.asuntomessut.fi/menneet-messut/menneet-asuntomessut, [Accessed 05-March-2014] (in Finnish)

20. Rogers, E.M., Diffusion of innovations, Free Press, New York, 2003.

21. Ymparisto.fi, The energy performance certificate for buildings, 2014, http://www.ymparisto.fi/energiatodistus, [Accessed 01-March-2014] (in Finnish)

22. Helsingin sanomat, It is a must to get an own house right away - popularity of element houses is rising, http://www.hs.fi/a1393047304644, [Accessed 05-March-2014] (in Finnish) 